\title{
Pulmonary capillary blood volume in women: normal values and the effect of oral contraceptives
}

\author{
A NTHONYSEATON ${ }^{1}$ \\ Department of Medicine, West Virginia University
}

\begin{abstract}
Pulmonary capillary blood volume $\left(\mathrm{V}_{\mathrm{c}}\right)$ was determined in 30 young women, 14 of whom were taking oral contraceptives. Duplicate estimates of $V_{c}$ in the 16 women not taking contraceptives showed a significant increase in the second half of the menstrual cycle. Formulae for prediction of $V_{c}$ in women were derived for the first and second halves of the cycle. $V_{c}$ was shown to be of the same order in women taking contraceptives containing oestrogen and progestogen as in those in the premenstrual phase of the cycle. Possible causes of these findings and their relevance to the diagnosis of pulmonary thromboembolic disease are discussed.
\end{abstract}

Oral contraceptives appear to have many different actions on the vascular system. On the one hand, they may cause vasodilatation (Goodrich and Wood, 1964) and an increase in blood volume (Walters and Lim, 1969) while, on the other, they may contribute to intravascular coagulation (Dugdale and Masi, 1969; Inman, Vessey, Westerholm, and Engelund, 1970) and endarteritis (Irey, Manion, and Taylor, 1970). In the investigation of obliterative disease of the pulmonary vascular bed it has been suggested that estimation of the pulmonary capillary blood volume $\left(\mathrm{V}_{\mathrm{c}}\right)$ may be a helpful diagnostic tool (Nadel et al., 1966). The present study was planned to determine the normal values for $V_{c}$ in females, and to find if oral contraceptive therapy alters these values.

\section{METHODS}

Thirty women, aged between 18 and 35 years, were studied. All were non-smokers or smoked fewer than five cigarettes per day. Fourteen of the subjects were taking oral contraceptives (oestrogen plus progestogen) at the time of study. The other 16 were studied at two separate times in the menstrual cyclebetween 7 and 10 days after and again between 2 and 4 days before the onset of menstruation. In addition, nine normal men were each studied on two occasions in order to determine the relative error of the techniques. The physical characteristics of the subjects and details of contraceptive therapy are given in Tables I and II.

The techniques used were based on those of McNeill, Rankin, and Forster (1958) using the formula

1Present addrcss: Sully Hospital, Penarth, Glamorgan
$1 / \mathrm{D}_{\mathrm{I}}=1 / \mathrm{D}_{\mathrm{m}}+1 \theta \mathrm{V}_{\mathrm{c}}$, derived by Roughton and Forster (1957), where $D_{L}=$ transfer factor of the lung for carbon monoxide, $D_{m}=$ diffusing capacity of the pulmonary membrane, and $\theta=$ the reaction rate of haemoglobin with carbon monoxide in vitro. Duplicate determinations of $D_{L}$ were made at three different alveolar oxygen tensions, using the method of Ogilvie, Forster, Blakemore, and Morton (1957) except that neon rather than helium was used in the gas mixture. For the low oxygen measurements, a gas containing $0.4 \%$ carbon monoxide, $0.4 \%$ neon, and $21 \%$ oxygen in nitrogen was used. For the high oxygen measurements $0.4 \%$ carbon monoxide and $0.4 \%$ neon in oxygen was used.

The subjects were studied in the sitting position, smokers not being tested until at least three hours after their last cigarette. Two single breath manoeuvres were carried out using the low oxygen gas. High oxygen gas was then substituted and the subjects carried out two further single breath manoeuvres. Finally, two more measurements of $D_{L}$ were made using the high oxygen gas after the subjects had breathed $100 \%$ oxygen for one to two minutes. In all cases care was taken to prevent a Valsalva manoeuvre and at least five minutes were allowed to pass between each test.

Neon and carbon monoxide in the gas samples were analysed by a Beckman gas chromatograph and oxygen tension was measured with an I.L. electrode. The subjects' total lung capacities were measured in a constant volume body plethysmograph (DuBois et al., 1956) and residual volume was obtained by subtraction of vital capacity after both volumes had been corrected to S.T.P.D.

CALCUlations Transfer factor was calculated from the formula of Ogilvie et al. (1957). The reaction rate of carbon monoxide with haemoglobin, $\theta$, was obtained from the formula $1 / \theta=0.33+0.0057 \quad \mathrm{P}_{\mathrm{c}} \mathrm{O}_{2}$, 
where $\mathrm{P}_{\mathrm{C}} \mathrm{O}_{2}$ is the oxygen tension in the pulmonary capillary. The derivation of $\theta$ is based on the work of Roughton and Forster (1957) assuming a value for $\lambda$ (the ratio of permeability to carbon monoxide of the membrane of the red cell to its interior) of $2 \cdot 5$. The pulmonary capillary oxygen tension was estimated from the expired alveolar oxygen tension $\left(\mathrm{P}_{\epsilon} \mathrm{O}_{2}\right)$ from

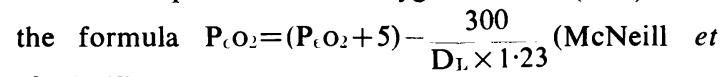
al., 1958).

A formula for regression of $1 / D_{L}$ on $1 / \theta$ was calculated using the method of least squares. The slope of this line represents $1 / V_{c}$ and the intercept gives the reciprocal of the diffusing capacity of the pulmonary membrane, $D_{m}$.

STATISTICAL METHODS In order to compare the results in the controls with those in the subjects taking con- traceptive tablets, values for $D_{L}, V_{c}$ and $D_{m}$ were divided by the subject's total lung capacity. The groups were then tested by the $t$ test for independent samples, the significant values for $t$ at the $5 \%$ level for these data being equal to or greater than $2 \cdot 048$.

To compare the results obtained in the control group at the two different stages of the cycle, the $t$ test for paired samples was used. For these data the significant value of $t$ at the $5 \%$ level was equal to or greater than $2 \cdot 131$.

Correlation coefficients $(r)$ between $D_{L}, V_{c}$ and $D_{m}$ and height, surface area and total lung capacity at S.T.P.D. were calculated in the controls at both stages of the cycle. The values of $r$ showing linearity but not a one to one relationship fall between 0.5 and 0.97 . The relative error of duplicate measurements in the male controls was calculated using an analysis of the components of variation.

T A B L E I

CONTROL SUBJECTS

\begin{tabular}{|c|c|c|c|c|c|c|c|c|c|c|c|}
\hline $\begin{array}{c}\text { Subject } \\
\text { No. }\end{array}$ & $\begin{array}{l}\text { Age } \\
(y r)\end{array}$ & $\begin{array}{l}\text { Height } \\
\text { (in) }\end{array}$ & \multicolumn{2}{|c|}{$\begin{array}{l}\text { Weight } \\
\text { (lb) } \\
\text { (a) }\end{array}$} & $\begin{array}{c}\text { Total Lung } \\
\text { Capacity } \\
\text { at STPD } \\
(\mathrm{ml})\end{array}$ & \multicolumn{2}{|c|}{$\begin{array}{l}\text { (DL) } \\
\text { Lung Transfer } \\
\text { Factor } \\
\left(\mathrm{ml} / \mathrm{min} / \mathrm{mmHg}_{\text {(a) }} \quad \text { (b) }\right.\end{array}$} & \multicolumn{2}{|c|}{ 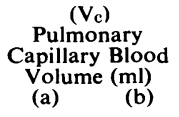 } & \multicolumn{2}{|c|}{ 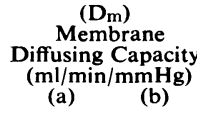 } \\
\hline $\begin{array}{r}1 \\
2 \\
3 \\
4 \\
5 \\
6 \\
7 \\
8 \\
9 \\
10 \\
11 \\
12 \\
13 \\
14 \\
15 \\
16\end{array}$ & $\begin{array}{l}18 \\
23 \\
20 \\
29 \\
23 \\
21 \\
22 \\
28 \\
18 \\
21 \\
25 \\
31 \\
28 \\
20 \\
19 \\
20\end{array}$ & $\begin{array}{l}62 \cdot 5 \\
64 \\
63 \\
63 \\
67 \\
60 \cdot 5 \\
67 \\
62 \\
65 \\
62 \\
69 \\
70 \\
69 \\
69 \\
70 \\
69\end{array}$ & $\begin{array}{l}108 \\
111 \\
120 \\
123 \\
136 \\
101 \\
170 \\
132 \\
135 \\
114 \\
143 \\
143 \\
168 \\
150 \\
166 \\
128\end{array}$ & $\begin{array}{l}108 \\
111 \\
127 \\
123 \\
137 \\
101 \\
172 \\
132 \\
135 \\
111 \\
143 \\
141 \\
170 \\
150 \\
166 \\
128\end{array}$ & $\begin{array}{l}2870 \\
2940 \\
3110 \\
3350 \\
3420 \\
3440 \\
3560 \\
3580 \\
3590 \\
3620 \\
3800 \\
4420 \\
5050 \\
5300 \\
5330 \\
5420\end{array}$ & $\begin{array}{l}20 \cdot 5 \\
25 \cdot 7 \\
26 \cdot 4 \\
22 \cdot 4 \\
25 \cdot 4 \\
35 \cdot 4 \\
30 \cdot 9 \\
26 \cdot 9 \\
25 \cdot 4 \\
26 \cdot 6 \\
23 \cdot 2 \\
29 \cdot 1 \\
44 \cdot 4 \\
41 \cdot 2 \\
41.40 \\
39 \cdot 9\end{array}$ & $\begin{array}{l}21 \cdot 3 \\
25 \cdot 8 \\
22 \cdot 9 \\
23 \cdot 5 \\
30 \cdot 5 \\
34 \cdot 7 \\
33 \cdot 3 \\
29 \cdot 7 \\
25 \cdot 9 \\
30 \cdot 7 \\
28 \cdot 8 \\
28 \cdot 7 \\
43 \cdot 5 \\
38 \cdot 4 \\
42 \cdot 4 \\
46 \cdot 6\end{array}$ & $\begin{array}{r}60.6 \\
57.4 \\
68.8 \\
57.3 \\
81.5 \\
73.4 \\
92.7 \\
74.0 \\
69 \cdot 3 \\
70.3 \\
74.6 \\
86.7 \\
138.9 \\
87.3 \\
119.0 \\
121.7\end{array}$ & $\begin{array}{r}69 \cdot 4 \\
84 \cdot 7 \\
75 \cdot 6 \\
63 \cdot 2 \\
95 \cdot 7 \\
94 \cdot 7 \\
96 \cdot 6 \\
72.6 \\
76 \cdot 0 \\
80 \cdot 3 \\
106 \cdot 3 \\
96 \cdot 4 \\
151 \cdot 7 \\
106 \cdot 3 \\
132 \cdot 1 \\
129 \cdot 5\end{array}$ & $\begin{array}{l}30 \cdot 7 \\
45 \cdot 3 \\
42 \cdot 4 \\
37 \cdot 9 \\
36 \cdot 6 \\
68 \cdot 4 \\
46 \cdot 2 \\
50 \cdot 0 \\
39 \cdot 8 \\
53 \cdot 0 \\
33 \cdot 4 \\
44 \cdot 2 \\
65 \cdot 6 \\
78 \cdot 7 \\
63 \cdot 2 \\
58 \cdot 6\end{array}$ & $\begin{array}{l}30 \cdot 0 \\
36 \cdot 2 \\
32 \cdot 7 \\
37 \cdot 7 \\
44 \cdot 7 \\
56 \cdot 2 \\
50 \cdot 9 \\
50 \cdot 2 \\
39 \cdot 5 \\
49 \cdot 6 \\
38 \cdot 9 \\
40 \cdot 3 \\
60 \cdot 5 \\
61 \cdot 2 \\
64 \cdot 1 \\
72 \cdot 1\end{array}$ \\
\hline $\begin{array}{l}\text { Mean } \\
\text { S.D. }\end{array}$ & $\begin{array}{r}22 \cdot 9 \\
4 \cdot 1\end{array}$ & $\begin{array}{r}65 \cdot 8 \\
3 \cdot 3\end{array}$ & $\begin{array}{r}134 \cdot 3 \\
21 \cdot 5\end{array}$ & $\begin{array}{r}134.7 \\
21.9\end{array}$ & $\begin{array}{r}3925 \\
881\end{array}$ & $\begin{array}{r}30 \cdot 3 \\
7 \cdot 7\end{array}$ & $\begin{array}{r}31.7 \\
7.7\end{array}$ & $\begin{array}{l}81 \cdot 5 \\
26 \cdot 3\end{array}$ & $\begin{array}{l}95 \cdot 7 \\
24.9\end{array}$ & $\begin{array}{l}49.6 \\
13.8\end{array}$ & $\begin{array}{l}47 \cdot 8 \\
12 \cdot 3\end{array}$ \\
\hline
\end{tabular}

$a=$ first half of menstrual cycle; $b=$ second nalf of menstrual cycle

T A B L E I I

SUBJECTS ON ORAL CONTRACEPTIVES

\begin{tabular}{|c|c|c|c|c|c|c|c|c|c|}
\hline $\begin{array}{c}\text { Subject } \\
\text { No. }\end{array}$ & $\begin{array}{l}\text { Age } \\
(y r)\end{array}$ & $\begin{array}{l}\text { Height } \\
\text { (in) }\end{array}$ & $\begin{array}{l}\text { Weight } \\
\text { (lb) }\end{array}$ & $\begin{array}{c}\text { Type of } \\
\text { Contraceptive } \\
\text { Therapy }\end{array}$ & $\begin{array}{c}\text { Time on Oral } \\
\text { Contraceptives } \\
(y r)\end{array}$ & $\begin{array}{l}\text { Total Lung } \\
\text { Capacity } \\
\text { at STPU } \\
(\mathrm{ml})\end{array}$ & $\underset{\substack{\mathrm{ml} / \mathrm{min} / \\
\mathrm{mm} \mathrm{Hg})}}{\mathrm{DL}}$ & $\begin{array}{l}V_{c} \\
(\mathrm{ml})\end{array}$ & $\underset{(\mathrm{ml} / \mathrm{min} /}{\mathrm{Dm}_{\mathrm{m}}}$ \\
\hline $\begin{array}{l}17 \\
18 \\
19 \\
20 \\
21 \\
22 \\
23 \\
24 \\
25 \\
26 \\
27 \\
28 \\
29 \\
30\end{array}$ & $\begin{array}{l}21 \\
25 \\
26 \\
22 \\
19 \\
24 \\
20 \\
24 \\
22 \\
27 \\
27 \\
25 \\
25 \\
23\end{array}$ & $\begin{array}{l}61 \\
60 \\
63 \\
63 \\
63 \\
64 \cdot 5 \\
60 \cdot 5 \\
65 \\
66 \\
63 \cdot 5 \\
64 \\
66 \\
67 \\
66 \cdot 5\end{array}$ & $\begin{array}{l}103 \\
152 \\
118 \\
116 \\
120 \\
149 \\
101 \\
153 \\
135 \\
123 \\
123 \\
113 \\
163 \\
127\end{array}$ & $\begin{array}{l}\text { Ovulen-21 } \\
\text { Ovulen-21 } \\
\text { Enovid-E } \\
\text { Ovral } \\
\text { Norinyl } \\
\text { Ortho-Novum } \\
\text { Ovral } \\
\text { Ortho-Novum } \\
\text { Ovulen-21 } \\
\text { Ovral } \\
\text { Ortho-Novum } \\
\text { Ortho-Novum } \\
\text { Norlestrin } \\
\text { Ovulen-21 }\end{array}$ & $\begin{array}{l}1 \\
3 \\
5 \\
0 \cdot 6 \\
1 \\
3 \\
0 \cdot 5 \\
4 \\
2 \\
0 \cdot 6 \\
4 \\
2 \cdot 5 \\
2 \cdot 5 \\
0 \cdot 6\end{array}$ & $\begin{array}{l}2790 \\
3110 \\
3390 \\
3440 \\
3520 \\
3520 \\
3570 \\
3600 \\
3690 \\
3730 \\
3740 \\
3790 \\
4030 \\
4380\end{array}$ & $\begin{array}{l}23 \cdot 4 \\
22 \cdot 4 \\
33 \cdot 9 \\
31 \cdot 3 \\
25 \cdot 5 \\
27 \cdot 7 \\
33 \cdot 2 \\
26 \cdot 2 \\
28 \cdot 1 \\
37 \cdot 0 \\
31 \cdot 7 \\
31 \cdot 8 \\
29 \cdot 4 \\
36 \cdot 9\end{array}$ & $\begin{aligned} 68 \cdot 0 \\
78 \cdot 5 \\
117 \cdot 7 \\
84 \cdot 8 \\
95 \cdot 2 \\
71 \cdot 0 \\
81 \cdot 8 \\
83 \cdot 9 \\
97 \cdot 0 \\
102 \cdot 4 \\
93 \cdot 5 \\
104 \cdot 3 \\
88 \cdot 4 \\
103 \cdot 5\end{aligned}$ & $\begin{array}{l}34 \cdot 5 \\
31 \cdot 1 \\
47 \cdot 0 \\
52 \cdot 1 \\
34 \cdot 4 \\
45 \cdot 3 \\
55 \cdot 9 \\
37 \cdot 7 \\
39 \cdot 5 \\
58 \cdot 1 \\
48 \cdot 6 \\
45 \cdot 6 \\
43 \cdot 8 \\
57 \cdot 6\end{array}$ \\
\hline $\begin{array}{l}\text { Mean } \\
\text { S.D. }\end{array}$ & $\begin{array}{r}23 \cdot 6 \\
2.6\end{array}$ & $\begin{array}{r}63 \cdot 8 \\
2 \cdot 2\end{array}$ & $\begin{array}{r}128 \\
19\end{array}$ & & $\begin{array}{l}2 \cdot 2 \\
1 \cdot 5\end{array}$ & $\begin{array}{r}3590 \\
377\end{array}$ & $\begin{array}{r}29.9 \\
4.6\end{array}$ & $\begin{array}{l}90.7 \\
13.9\end{array}$ & $\begin{array}{l}45 \cdot 1 \\
8 \cdot 85\end{array}$ \\
\hline
\end{tabular}


RESULTS

The results in the control women in the two stages of the menstrual cycle are recorded in Table $I$ and in the women taking oral contraceptives in Table II. When the values for DL, $\mathrm{V}_{c}$, and $D_{m}$ in the two stages of the cycle are compared, there is found to be a significant increase in $V_{c}$ in the second half of the cycle $(t=5.07$, critical value for $t=2.131$ ) while $\mathrm{D}_{\mathrm{L}}$ and $\mathrm{D}_{\mathrm{m}}$ do not vary significantly $(t=1.63$ and -1.08 respectively). Comparing the subjects on contraceptive therapy with the controls, the only significant difference found was in $V_{c}$ corrected for total lung capacity between the controls during the first half of the cycle and the subjects on contraceptives (Tables III and IV).

T A B L E I I I

MEAN RESULTS IN CONTROLS AND SUBJECTS ON ORAL CONTRACEPTIVES

\begin{tabular}{|c|c|c|c|c|c|c|c|}
\hline & \multirow{3}{*}{$\begin{array}{l}\text { No. } \\
\text { of } \\
\text { Sub- } \\
\text { jects }\end{array}$} & \multirow{2}{*}{\multicolumn{2}{|c|}{$\begin{array}{c}\text { DL } \\
\text { Total Lung } \\
\text { Capacity } \\
(\mathrm{ml} / \mathrm{min} / \mathrm{mm} \\
\mathrm{Hg} / \mathrm{l})\end{array}$}} & \multirow{2}{*}{\multicolumn{2}{|c|}{$\frac{V_{c}}{\begin{array}{c}\text { Total Lung } \\
\text { Capacity } \\
(\mathrm{ml} / \mathrm{l})\end{array}}$}} & \multirow{2}{*}{\multicolumn{2}{|c|}{$\begin{array}{c}\mathrm{Dm}_{\mathrm{m}} \\
\text { Total Lung } \\
\text { Capacity } \\
(\mathrm{ml} / \mathrm{min} / \mathrm{mm} \\
\mathrm{Hg} / \mathrm{l})\end{array}$}} \\
\hline & & & & & & & \\
\hline & & Mean & S.D. & Mean & S.D. & Mean & S.D. \\
\hline $\begin{array}{l}\text { First half of cycle } \\
\text { Second half of cycle } \\
\text { Subjects on pill }\end{array}$ & $\begin{array}{l}16 \\
16 \\
14\end{array}$ & $\begin{array}{l}7 \cdot 79 \\
8 \cdot 09 \\
8 \cdot 32\end{array}$ & $\begin{array}{l}1.05 \\
0.96 \\
0.97\end{array}$ & $\begin{array}{l}21 \cdot 15 \\
24 \cdot 44 \\
25 \cdot 30\end{array}$ & $\begin{array}{l}2.92 \\
3 \cdot 49 \\
3 \cdot 44\end{array}$ & $\begin{array}{l}12 \cdot 73 \\
12 \cdot 20 \\
12 \cdot 53\end{array}$ & $\begin{array}{l}2 \cdot 70 \\
1 \cdot 85 \\
2 \cdot 02\end{array}$ \\
\hline
\end{tabular}

T A B LE I V

$t$ VALUES-COMPARISON OF CONTROLS WITH SUBJECTS TAKING ORAL CONTRACEPTIVES

\begin{tabular}{l|cc}
\hline & $\begin{array}{c}\text { Controls } \\
\text { (1st half cycle) } v \\
\text { Contraceptives }\end{array}$ & $\begin{array}{c}\text { Subjects on } \\
\text { Oral }\end{array}$ \\
\hline $\begin{array}{l}t \\
\text { Transfer factor }\end{array}$ & $\begin{array}{c}\text { Controls } \\
\text { Pulmonary capillary } \\
\text { blood volume }\end{array}$ \\
$\begin{array}{l}\text { Membrane diffusing } \\
\text { capacity }\end{array}$ & -1.50 & -0.65 \\
\hline
\end{tabular}

Critical value for $t= \pm 2 \cdot 048$ at $5 \%$ level of significance.

From the duplicate measurements in the male controls, the relative error of repeated determinations was found to be $5.6 \%$ for $D_{L}, 7.3 \%$ for $V_{c}$, and $11 \%$ for $D_{m}$ (Table V). The results were also found to be repeatable for three women in whom duplicate measurements were made at the same phase of the menstrual cycle (Table VI).

The relationships between $D_{L}, V_{c}, D_{m}$ and height, surface area and total lung capacity were tested in the controls at both stages of the cycle. The values of $r$ are given in Table VII. The best predictor of $D_{L}, V_{c}$, and $D_{m}$ at either stage is total lung capacity (at S.T.P.D.). Prediction formulæ
T A B L E V

DUPLICATE DETERMINATIONS IN MALES

\begin{tabular}{|c|c|c|c|c|c|c|}
\hline \multirow[t]{2}{*}{ Subject } & \multicolumn{2}{|c|}{$\underset{(\mathrm{ml} / \mathrm{min} / \mathrm{mmHg})}{\mathrm{DL}}$} & \multicolumn{2}{|c|}{$\begin{array}{l}\mathrm{V}_{\mathrm{c}} \\
(\mathrm{ml})\end{array}$} & \multicolumn{2}{|c|}{$\underset{(\mathrm{ml} / \mathrm{min} / \mathrm{mmHg})}{D_{\mathrm{m}}}$} \\
\hline & 1 & 2 & 1 & 2 & 1 & 2 \\
\hline $\begin{array}{l}\mathrm{a} \\
\mathrm{b} \\
\mathrm{c} \\
\mathrm{d} \\
\mathrm{e} \\
\mathbf{f} \\
\mathrm{g} \\
\mathrm{h} \\
\mathrm{i}\end{array}$ & $\begin{array}{l}31.2 \\
31.6 \\
32.5 \\
35.4 \\
40 \cdot 1 \\
39.3 \\
43.3 \\
42.3 \\
48.7\end{array}$ & $\begin{array}{l}34 \cdot 2 \\
34.5 \\
393 \\
37.6 \\
39.6 \\
41 \cdot 2 \\
43.5 \\
45.1 \\
51.9\end{array}$ & $\begin{array}{r}101.3 \\
79.5 \\
122.3 \\
104.0 \\
175.0 \\
123.5 \\
122.3 \\
111.5 \\
163.1\end{array}$ & $\begin{array}{r}105.8 \\
97.7 \\
114.4 \\
91.5 \\
165.3 \\
104.0 \\
140.2 \\
121.0 \\
164.8\end{array}$ & $\begin{array}{l}45 \cdot 1 \\
52 \cdot 8 \\
44 \cdot 3 \\
53 \cdot 7 \\
48 \cdot 3 \\
57 \cdot 8 \\
68 \cdot 2 \\
69 \cdot 4 \\
69 \cdot 9\end{array}$ & $\begin{array}{l}52.4 \\
53.1 \\
59.9 \\
67.1 \\
52.4 \\
68.9 \\
63.5 \\
60.5 \\
76.7\end{array}$ \\
\hline $\begin{array}{l}\text { Relative } \\
\text { error }\end{array}$ & \multicolumn{2}{|c|}{$5.6 \%$} & \multicolumn{2}{|c|}{$7 \cdot 3 \%$} & \multicolumn{2}{|c|}{$11 \%$} \\
\hline
\end{tabular}

T A B L E V I

DUPLICATE DETERMINATIONS IN WOMEN AT SAME STAGE OF MENSTRUAL CYCLE

\begin{tabular}{|c|c|c|c|c|}
\hline \multicolumn{2}{|c|}{ Subject } & $\underset{(\mathrm{ml} / \mathrm{min} / \mathrm{mmHg})}{\mathrm{DL}}$ & $\underset{(\mathrm{ml})}{\mathrm{V}_{\mathrm{c}}}$ & $\underset{(\mathrm{ml} / \mathrm{min} / \mathrm{mmHg})}{D_{\mathrm{m}}}$ \\
\hline F.R. & $\begin{array}{l}1 \\
2\end{array}$ & $\begin{array}{l}30 \cdot 7 \\
31 \cdot 1\end{array}$ & $\begin{array}{l}80 \cdot 3 \\
87 \cdot 5\end{array}$ & $\begin{array}{l}49 \cdot 6 \\
48 \cdot 9\end{array}$ \\
\hline J.S. & $\begin{array}{l}1 \\
2\end{array}$ & $\begin{array}{l}29 \cdot 9 \\
26.9\end{array}$ & $\begin{array}{l}74 \cdot 0 \\
72 \cdot 6\end{array}$ & $\begin{array}{l}50 \cdot 0 \\
50 \cdot 2\end{array}$ \\
\hline M.P. & $\begin{array}{l}1 \\
2\end{array}$ & $\begin{array}{l}25 \cdot 7 \\
24 \cdot 9\end{array}$ & $\begin{array}{l}70 \cdot 9 \\
72 \cdot 8\end{array}$ & $\begin{array}{l}40 \cdot 0 \\
37 \cdot 5\end{array}$ \\
\hline
\end{tabular}

T A B LE VII

CORRELATION COEFFICIENTS IN CONTROL SUBJECTS

\begin{tabular}{|c|c|c|c|c|c|c|}
\hline & \multicolumn{2}{|c|}{ Transfer Factor } & \multicolumn{2}{|c|}{$\begin{array}{c}\text { Pulmonary } \\
\text { Capillary } \\
\text { Blood Volume }\end{array}$} & \multicolumn{2}{|c|}{$\begin{array}{c}\text { Membrane } \\
\text { Diffusing } \\
\text { Capacity }\end{array}$} \\
\hline & (a) & (b) & (a) & (b) & (a) & (b) \\
\hline $\begin{array}{l}\text { Total lung } \\
\text { capacity } \\
\text { Height } \\
\text { Surface area }\end{array}$ & $\begin{array}{l}0.86 \\
0.50 \\
0.54\end{array}$ & $\begin{array}{l}0.88 \\
0.58 \\
0.56\end{array}$ & $\begin{array}{l}0.85 \\
0.70 \\
0.74\end{array}$ & $\begin{array}{l}0.83 \\
0.75 \\
0.71\end{array}$ & $\begin{array}{l}0 \cdot 70 \\
0 \cdot 22 \\
0 \cdot 26\end{array}$ & $\begin{array}{l}0.83 \\
0.43 \\
0.44\end{array}$ \\
\hline
\end{tabular}

for these measurements based on total lung capacity at S.T.P.D. (TLC) are given below:

(a) First half of the cycle

$$
\begin{aligned}
& D_{L}=7.42 \text { TLC }+1.37 \quad(r=0.86) \\
& V_{c}=23.17 \text { TLC }-7.6(r=0.85) \\
& D_{m}=10.98 \quad T L C+6.54 \quad(r=0.70)
\end{aligned}
$$

(b) Premenstrually

$\mathrm{D}_{\mathrm{L}}=7.64 \mathrm{TLC}+1.70 \quad(\mathrm{r}=0.88)$

$\mathrm{V}_{\mathrm{c}}=23.4 \mathrm{TLC}+3.84(\mathrm{r}=0.83)$

$\mathrm{D}_{\mathrm{m}}=11.61$ TLC $+2 \cdot 21 \quad(\mathrm{r}=0.83)$.

\section{DISCUSSION}

Estimation of pulmonary capillary blood volume has been suggested as a method for investigation 
of occlusive disease of the small pulmonary arteries and may be of particular value in subjects with multiple small emboli leading to pulmonary hypertension (Nadel et al., 1966). However, the value of such a test must depend on a knowledge of the results obtained in normal subjects.

Although a number of authors have recorded normal values for $V_{c}$ and $D_{m}$ in their laboratories (McNeill et al., 1958; Lewis, Lin, Noe, Komisaruk, 1958; Ross, Maddock, and Ley, 1961; Daly, Ross, and Behnke, 1963; McCredie, Lovejoy, and Yu, 1964; and Krumholz, 1966), there has been little agreement on the normal range. In particular, values for $D_{m}$ have varied very widely in different series and even in different patients in the same series. However, most authors find the techniques show good repeatability in the same individual. Bucci, Cook, and Barrie (1961) produced prediction formulæ for $V_{c}$ and $D_{m}$ based on total lung capacity, height and surface area, finding no essential difference between male and female subjects.

The results reported in the present paper show reasonable repeatability in the male subjects and in the three female subjects in whom the test was repeated at the same time in the cycle. The values recorded for $D_{\mathrm{I}}$ and $\mathrm{V}_{\mathrm{c}}$ are somewhat higher than in other series. This may be related to the use of the body plethysmograph for measuring residual volume, as this does give higher values than helium or neon methods (Reichel, 1969), although Daly et al. (1963) used a similar technique without getting such high values.

An increase in plasma volume in the luteal phase of the menstrual cycle has been suspected on the basis of the fall in haematocrit and gain in weight that may be found at this time (Danforth, Boyer, and Graff, 1946). At the same time in the cycle, venous tone is decreased (McCausland, Holmes, and Trotter, 1963), this effect also occurring during pregnancy and in subjects on oestrogen-progestogen contraceptives (Goodrich and Wood, 1964). Recently, it has been demonstrated that subjects show an increase in weight, plasma volume, and cardiac output when they start taking these contraceptives (Walters and Lim, 1969). Vascular changes during the menstrual cycle have been demonstrated directly in the conjunctival vessels, using slit-lamp microscopy (Landesman, Douglas, Dreishpoon, and Holze, 1953). At this site vascular dilatation occurs in the luteal phase of the cycle, followed by increased vasomotion and then vascular spasm immediately premenstrually.

Logan (1967) noticed that pulmonary capillary blood volume in five normal females was greater in the second than in the first half of the cycle, though the difference was not statistically significant. The present study shows that there is a significant variation in $V_{c}$, though not in $D_{L}$ or $D_{m}$, through the menstrual cycle. In all subjects studied save one, an increase in $V_{c}$ occurred the week before menstruation and this suggests that either progesterone or its combination with oestrogen is responsible. Confirmation of this comes from the finding that $V_{c}$ in subjects on oestrogen-progestogen tablets is also raised compared to controls studied in the first half of the cycle.

The increase in $\mathrm{V}_{\mathrm{c}}$ is not likely to be related to an increase in plasma volume, as determination of $V_{c}$ depends on the amount of haemoglobin rather than plasma in the pulmonary capillaries. In general, there is a slight drop in haematocrit premenstrually (Danforth et al., 1946) which, if it affected the estimation of $V_{c}$ at all, would cause an artefactually low result. A more likely explanation of the changes observed is that progesterone, either alone or with oestrogen, causes distension of the pulmonary capillary bed, possibly secondary to an action on the arterioles or venules similar to that observed at other sites (Landesman et al., 1953; McCausland et al., 1963; and Goodrich and Wood, 1964). It is not easy to understand why these hormones should have a dual action on respiration, acting both as a respiratory stimulant (Goodland, Reynolds, McCoord, and Pommerenke, 1953; Döring, Loeschcke, and Ochwadt, 1950) and as a pulmonary vasodilator. Whether this second effect may contribute to the hypocapnia of pregnancy and of the luteal phase by reducing the physiological dead space is a matter for speculation.

From a practical point of view, if a state of pulmonary vasodilatation exists in subjects on oral contraceptives, arteriovenous shunts may become opened and cause zones of apparent underperfusion on lung scans which might be attributed to vascular occlusion. In such circumstances determination of $\mathrm{V}_{c}$ should be helpful. If $\mathrm{V}_{c}$ is found to be higher than the predicted normal for females in the first half of the cycle, significant occlusion of the pulmonary vascular bed is unlikely to be present. On the other hand, a value for $\mathrm{V}_{\mathrm{c}}$ lower than this predicted normal should arouse a strong suspicion of multiple pulmonary emboli.

The author thanks Mr. Andrew Jacobs and Mr. Robert Reger for the statistical analysis. 


\section{REFERENCES}

Bucci, G., Cook, C. D., and Barrie, H. (1961). Studies of respiratory physiology in children, V. Total lung diffusion, diffusing capacity of pulmonary membrane, and pulmonary capillary blood volume in normal subjects from 7 to 40 years of age. J. Pediat., 58, 820 .

Daly, W. J., Ross, J. C., and Behnke, R. H. (1963). The effect of changes in the pulmonary vascular bed produced by atropine, pulmonary engorgement and positivepressure breathing on diffusing and mechanical properties of the lung. J. clin. Invest., 42, 1083.

Danforth, D. N., Boyer, P. K., and Graff, S. (1946). Fluctuations in weight, hematocrit and plasma protein with the menstrual cycle. Endocrinology, 39, 188.

Döring, G. K., Loeschcke, H. H., and Ochwadt, B. (1950). Weitere Untersuchungen über die Wirkung der Sexualhormone auf die Atmung. Pflïger's Arch. ges. Physiol., 252, 216.

DuBois, A. B., Botelho, S. Y., Bedell, G. N., Marshall, R., and Comroe, J. H. (1956). A rapid plethysmographic method for measuring thoracic gas volume. J. clin. Invest., 35, 322.

Dugdale, M., and Masi, A. T. (1969). Effects of the oral contraceptives on blood clotting. In Second Report on the Oral Contraceptives, pp. 43-51. Advisory Committee on Obstetrics and Gynecology, Federal Drug Administration, Washington, D.C.

Goodland, R. L., Reynolds, J. G., McCoord, A. B., and Pommerenke, W. T. (1953). Respiratory and electrolyte effects induced by estrogen and progesterone. Fertil and Steril., 4, 300.

Goodrich, S. M., and Wood, J. E. (1964). Peripheral venous distensibility and velocity of venous blood flow during pregnancy or during oral contraceptive therapy. Amer.J. Obstet. Gynec., 90, 740.

Inman, W. H. W., Vessey, M. P., Westerholm, B., and Engelund, A. (1970). Thromboembolic disease and the steroidal content of oral contraceptives. A report to the Committee on Safety of Drugs. Brit. med. J., 2, 203.

Irey, N. S., Manion, W. C., and Taylor, H. B. (1970). Vascular lesions in women taking oral contraceptives. Arch. Path., 89, 1.

Krumholz, R. A. (1966). Pulmonary membrane diffusing capacity and pulmonary capillary blood volume: an appraisal of their clinical usefulness. Amer. Rev. resp. Dis., 94, 195.
Landesman, R., Douglas, R. G. Dreishpoon, G., and Holze, E. (1953). The vascular bed of the bulbar conjunctiva in the normal menstrual cycle. Amer. J. Obstet. Gynec., 66,988.

Lewis, B. M., Lin, T.-H., Noe, F. E., and Komisaruk, R. (1958). The measurement of pulmonary capillary blood volume and pulmonary membrane diffusing capacity in normal subjects; the effects of exercise and position. J. clin. Invest., 37, 1061.

Logan, W. F. W. E. (1967). The pulmonary capillary bed in pregnancy and mitral stenosis. M.D. Thesis, University of Liverpool.

McCausland, A. M., Holmes, F., and Trotter, A. D. (1963). Venous distensibility during the menstrual cycle. Amer. J. Obstet. Gynec., 86, 640.

McCredie, R. M., Lovejoy, F. W., and Yu, P. N. (1964). Pulmonary diffusing capacity and pulmonary capillary blood volume in patients with intracardiac shunts. J. Lab. clin. Med., 63, 914.

McNeill, R. S., Rankin, J., and Forster, R. E. (1958). The diffusing capacity of the pulmonary membrane and the pulmonary capillary blood volume in cardiopulmonary disease. Clin. Sci., 17, 465.

Nadel, J. A., Gold, W. M., Jennings, D. B., Wright, R. R., and Fudenberg, H. H. (1966). Unusual disease of pulmonary arteries with dyspnea. Amer. J. Med., 41, 440.

Ogilvie, C. M., Forster, R. E., Blakemore, W. S., and Morton, J. W. (1957). A standardized breath holding technique for the clinical measurement of the diffusing capacity of the lung for carbon monoxide. J. clin. Invest., 36, 1.

Reichel, G. (1969). Differences between intrathoracic gas measured by the body plethysmograph and functional residual capacity determined by gas dilution methods. In International Symposium on Body Plethysmography. Prog. Resp. Res., 4, 188.

Ross, J. C., Maddock, G. E., and Ley, G. D. (1961). Effect of pressure suit inflation on pulmonary capillary blood volume. J. appl. Physiol., 16, 674.

Roughton, F. J. W., and Forster, R. E. (1957). Relative importance of diffusion and chemical reaction rates in determining rate of exchange of gases in the human lung. With special reference to true diffusing capacity of pulmonary membrane and volume of blood in the lung capillaries. J. appl. Physiol., 11, 290.

Walters, W. A. W., and Lim, Y. L. (1969). Cardiovascular dynamics in women receiving oral contraceptive therapy. Lancet, 2, 879. 